\title{
8 The life course perspective in social gerontology
}

\author{
Barbara Szatur-Jaworska
}

In this chapter, the research perspective is understood as the cognizant subject's point of view, which consists in distinguishing a certain part from the scope of the complex research subject and describing it using specific terms. The life course perspective is such an understanding of a separate research perspective in social gerontology. Apart from the life course perspective, we can distinguish the life cycle perspective in social research. Both are important in social gerontology, yet, nowadays, the mainly developed perspective is life course research.

This chapter points to cognitive and practical values of social research of old age using the life course perspective. The methodological and conceptual limitations of conducting such studies are also discussed. Serious methodological challenges are posed by using dynamic research schemes and the specificity of the elderly as respondents.

\section{Introduction}

Changes that occur in the life of human beings with the lapse of time are of interest to various scientific disciplines, with theories based on various ontological, epistemological and methodological assumptions. Developmental psychology, which has created a vision of human development throughout one's life - including in old age - has an important role in the development of research on changes in human life. This is one of the fundamental assumptions of social gerontology that allows us to treat old age as a phase of life that is no worse than previous phases and that is characterized (just like other phases of life) by its internal dynamics. Social gerontology looks at old age in the context of the whole human life, using and developing theories created in sociology, psychology, demography, pedagogy, medicine and social policy. Scientists dealing with changes that take place in the timeline of people's lives determine the subject of their research using many terms: life cycle, life course, trajectory, life span, biography and others. Some use these terms interchangeably, but there are also those who seek different definitions for each one and associate them with different research perspectives. In social gerontology, as an interdisciplinary science, the co-existence and combination of different research perspectives is fully justified. It is similar to combining several research methods in a single project, the choice of which results from the adoption of specific theoretical assumptions.

Among the concepts mentioned in the introduction, I consider life cycle and life course to be fundamental for social gerontology. Each of these terms is fuzzy. Often, the authors do not give precise definitions and their interpretation is left to the readers' intuition. A short conceptualization of each of these concepts is therefore needed in order to provide a clear framework for further consideration. 
The concept of the life cycle derives from the observation of natural phenomena, the most obvious example of which is the repetition of seasons. Researchers dealing with the biological cycle of human life focus on genetically programmed changes common for the whole species, which take place in the human body from conception to natural death. The term "life cycle" is also used as a theoretical category in social sciences. Changes in the life of a single person are described as linear, stadial or cyclic-phase (Brzezińska, 2000, pp. 61-98). In the life of the entire species, the changes take place cyclically, i.e., they repeat themselves. Researchers using the term "life cycle" assume that the changes they are interested in occur in a constant sequence, i.e., everyone goes through the same phases of life in the same order (Dobrowolska, 1992; Rysz-Kowalczyk, 1996). What is more, all people go through the same cycle (unless they died prematurely) and this sequence of phases is repeated in subsequent generations (cohorts). What is important, it is assumed that it is not possible to go back to the phase that has already been experienced once. Of course, the criteria for separating the phases of the cycle understood in this way are different in each theoretical concept. It is generally accepted that the basic structure of the life cycle is determined by the rhythm of biological changes, but individual psychological characteristics of people and the socio-cultural norms that vary in time and space overlap with this rhythm. In gerontological research, the term "life cycle" is used in the concepts of developmental psychology, economics, social policy science, demography and sociology. The ontological status of this concept is different, as it can be treated in three ways: (1) as a name of a real, objective process, (2) as a name of a socially produced, normative construction, (3) as a metaphor. A separate research perspective is being built around the life cycle category, which focuses on: typical (and even universal) changes, supra-individual specificity of particular life phases (described by such terms as psychosocial ego development (Erikson), intelligence development (Piaget), interpersonal competence development (Selman), developmental tasks (Haviqhurst) (cited after Brzezińska, Appelt and Ziółkowska, 2015, pp. 76-86), regularities in transitions between life phases, life cycle disturbances, phase deformations (Rysz-Kowalczyk, 1996), dependencies between consecutive phases, etc.

In connection with the blurring boundaries between the traditionally distinguished life phases (e.g., biological rejuvenation of the organism, learning as a developmental task assigned not only to childhood but also to other phases), the process described as deinstitutionalization and re-institutionalization of the life cycle and the growing scope of people's freedom in shaping their individual destinies, the popularity of the life course category is growing in social sciences. Compared to "life cycle", the concept more strongly exposes the historical variability of life scenarios and takes into account the diversity of transitional periods between life stages (Green, 2017, p. 22), although in some respects this category is described similarly to life cycle. "Life course" has many definitions in the world scientific literature. In my opinion, the definition of the Polish sociologist Danuta Dobrowolska is very useful for considerations in the field of social gerontology:

I would describe the course of life as a sequence of human experiences and behaviours (including actions) related to specific situations in which a person finds himself from birth to death. They are conditioned both by the transformation of the organism and psyche of a given individual, as well as by changing external conditions in the broad sense of the word. ... other people and their products also participate in the course of life of an individual. 
The life course is divided into stages which, among other things, differ from the phases in the life cycle in that there is a - limited - possibility to return to a once experienced stage (e.g., after a long break it is possible to return to school, start a family again, give up work and after some time return to it). The concept of the life course, like the life cycle, sets out a specific research perspective. ${ }^{1}$

The aim of this chapter is to describe the life course perspective in social gerontology, to indicate its values and limitations in gerontological research and to characterize key empirical research patterns used in social research on old age and elderly people.

\section{The life course perspective: a conceptualization}

The life course perspective has been present in gerontological research for many years. Its ontological and epistemological assumptions are developed mainly by the sociology of the course of life (life course sociology) ${ }^{2}$ and life span psychology. ${ }^{3}$ Both these disciplines provide key theoretical assumptions to which both sociological and psychological research, pedagogical and economic research, social policy science, etc., are subordinate.

In determining the essence of the course of life, one should refer to Martin Kohli's analysis, which many years ago drew attention to the dual understanding in science of the category of life course: as a social construction and as a process of shaping human personality in the process of socialization (cited after Hajduk 2001, pp. 41-42).

Conceptualization of the course of life as a social construct assumes that it is a collection of social norms and principles, which are guarded by social institutions. These norms and principles determine how a person's life should proceed in order to properly serve society. In addition, they regulate the individual's relationship with his or her immediate and distant environment, law, religion, etc. They also regulate the individual's relationship with his or her surroundings, law, religion, etc. Individuals are expected to behave and make choices that are consistent with the social construct of the course of life. ${ }^{4}$ There are many such social structures in every society, because they are different for women and men, for people belonging to different social groups or cultural traditions. As demonstrated by Jean-François Guillaume (2005), in our cultural circle, the life course pattern has been created for a very long time under the influence of the dominant role of men in society and the key importance of physical effort in the creation of material foundations of life.

The social construction of the course of life is characterized by researchers in different ways. For example, the Polish researcher Edward Hajduk wrote that it corresponds to "the concept of a series of social roles that a person undertakes and fulfils throughout his or her life" (2001, p. 48). In addition to social roles and the associated patterns of thematic biographies/careers/trajectories (educational, family, professional, etc.), the social construction of the course of life also takes into account the typical social environments in which people live (e.g., family, co-workers), sequence of roles and social environments, patterns of orientation (thanks to which the individual knows what biographical scenarios he or she potentially has to choose and whether these choices are in line with the desired state standard; social institutions that more or less influence the course of life) links between the stages of life (social age) and calendar age, and typical critical events (Hajduk, 2001, pp. 46-48). In the construction of the course of life, its stages are distinguished. Researchers indicate the following formal criteria that are used to distinguish life stages: (1) typicality (a high probability that units at a stage in one day will reach the expected, typical next stage); (2) sequencing (life stages occur according to a set order), (3) definite duration of the stage (during this time human life is not constant, each stage has its own dynamics), 
(4) irreversibility of the transition from one stage to the next, (5) relative universality (social reorganization of life associated with entering a given stage is proposed to all individuals having access to it) (Lalive d'Epinay, Cavalli and Guilley, 2005, pp. 67-68).

Traditional life course structures have assumed a one-way transition from one social role to another (e.g., from student to employee, from employee to pensioner). This one-way street has now been questioned, as adults are expected, for example, to combine the role of an employee with that of a student (the idea of life-long learning) or pensioner and an employee, and to return to the previously performed and abandoned social roles (e.g., for a long time, experts have been discussing planning career breaks for upgrading or changing qualifications).

Social constructions of the life course can be treated as part of the culture of the society. ${ }^{5}$ They are normative in nature. They are both the cause and effect of individuals' behaviors and attitudes. They are present in collective consciousness (as cultural messages, patterns of socially accepted behavior) and in individual consciousness (they reflect cultural patterns, but modified by personal aspirations, experiences, assessment of one's own social position, etc.). In the approach discussed here, the life course study concerns both the products of collective life and individual imaginations. The course of life and its stages are also treated in science as social representations (Roselli, 2015). The products of collective life to be researched are, for example, media messages, colloquial language, works of art, curricula. In the case of individual images concerning the preferred life patterns, sources of knowledge about them are statements from people, found (e.g., in diaries) or triggered (e.g., in interviews). In the research of the course of life understood as a social construction, the so-called qualitative methods are used first of all.

In the latter conceptualization, the life course is treated as an empirically experienced process of biological, psychological and social changes. Researchers using this conceptualization deal with actually implemented patterns of changes in the lives of individuals and cohorts. Such research is most characteristic of sociology, psychology and pedagogy, but also occurs in demography and social policy science. The life dynamics of specific persons and the cohorts created by them are examined, and the events, experiences, attitudes, ways of fulfilling social roles, the course of detailed careers/trajectories (e.g., educational, professional, familial) are examined. Researchers look for similarities and differences in the ways of shaping the lifetime. These methods depend on biological, psychological, situational (at different levels of social and economic life) and volitional factors. Biographical patterns functioning in social environments that are reference groups for an individual are also important. The course of life is therefore perceived as a result of various factors: individual, cultural, social, natural, economic and political. Researchers of the course of life analyze many aspects of human development in relation to various contextual factors. It is also assumed that the relationship between

changes in the individuals and their socio-cultural environment, seen over time ... is two-way in nature, which means that changes in the living environment of individuals trigger and/or sustain changes in their individual development plan, while the activity undertaken in many different areas directly or indirectly causes changes in this environment.

(Brzezińska, Appelt and Ziółkowska, 2015, p. 15)

According to Susan McDaniel and Paul Bernard (2011, p. 2), the life course perspective consists of four basic analytical principles: (1) everyday human experiences create a 
trajectory that runs from birth to death; (2) the patterns of life course evolve in many interrelated spheres; (3) through social links, the individual's life course influences that of others; (4) life course is shaped by a variety of local and national contexts, and at the same time, these contexts are shaped by the life course of individuals. It is therefore important for a life course perspective to capture the interdependencies between the different dimensions of the individual's life, as well as to explore the interaction between the individual's life and the life of their loved ones. Analyses are conducted on a time axis with simultaneous consideration of the mutual interactions indicated here. As noted by Nancy Côté (2013: 184), the life course perspective allows us to capture social phenomena in the long term, placing the individuals, their representations, experiences, actions, at the center of the analysis. The author considers that the most appropriate conceptualization of the life course is treating it as a set of different trajectories (familial, professional, health-related, etc.).

Using a life course perspective (defined as an empirically observable process), researchers analyze what has already happened (describe and explain past events and their dynamics), diagnose the current stage of life of the respondents (cohorts) (often the subject of such research are moments of transition between life stages, events being potential turning points) and forecast how the current life course of the respondents and cohorts will affect their future fate. Furthermore, the subject of research can be life plans, which people make for themselves and for their close ones. The life course (as an empirically observable process) is therefore related to descriptive, diagnostic and prognostic research. It is also possible to conduct research that seeks to explain the cause and effect relationships between events that have occurred in different careers (e.g., the influence of professional biography on the family biography) and the relationship between the life course of various individuals. The subjects of observation are the individuals and their social environment (other individuals, family, institutions, etc.). Quantitative (e.g., surveys) and qualitative (e.g., biographical interviews) methods are used in research belonging to the current study discussed here.

\section{Advantages and limitations of the life course perspective in gerontological research}

In social gerontology, the first advantage of a life course perspective is the connection between the state in which an individual enters the phase of old age and the stages he or she has already experienced. The insight into the human past makes it possible to determine the underlying causes of the opportunities and limitations that arise in old age. The insight into the past of the ageing cohorts also allows us to formulate hypotheses on the relationship between their migration, educational, occupational, health-related and social biography (the extent to which welfare state institutions were used in the past) and the current diversity of the elderly population in terms of their life situation, lifestyle, views and expectations. For example, a small sample survey of poor elderly people (their main source of income was social assistance benefits) I carried out showed differences between women and men in terms of pathways to old age deprivation and strategies to deal with elderly people's poverty (Szatur-Jaworska, 2000).

Second, the application of a life course perspective is essential in research aimed at determining when old age begins and the resulting variability in the boundaries of old age. This is one of the fundamental questions of gerontology.

Third, the adoption of a life course perspective makes it possible to capture the patterns of variability in the course of the old age phase, track its dynamics, determine the timing of 
the occurrence of breakthrough moments typical of old age (e.g., in the PolSenior studies, we discovered that in Poland, women became single as a result of divorce or widowhood earlier than men; Szatur-Jaworska, 2014), capture the typical age ranges in which members of a given society enter particular stages of old age (from early to late old age).

Fourth, research conducted from the life course perspective makes it possible to determine to what extent the life course of older people - at earlier stages and in old age - is disturbed and distorted by institutional and situational factors of a systemic nature (e.g., unequal treatment of women and men, mass unemployment, chronic poverty), and to what extent it results from wrong decisions of people, their dysfunctional behaviors, etc. For example, such an analytical distinction can be made by studying processes such as social marginalization or premature loss of life independence on the basis of biographical materials and intersubjective sources. As Barbara Rysz-Kowalczyk writes,

this property of the concept of the course of life is all the more valuable as radical social changes occur in a given historical period, which in a short time change the world of an individual so that the type of his earlier experiences and knowledge may prove to be useless and insufficient to meet the requirements of the previously chosen way of life.

Fifth, the life course perspective allows us to reconstruct the individual biographies and social conditions in which people grew up and lived their adult lives. Thanks to it, we can create a multidimensional social history.

Sixth, the life course perspective is useful for political decision-makers, as the resulting image of the social situation better reflects the reality in which social actors functioned and function, which allows for the construction of a public policy better suited to their needs (MacDaniel and Bernard, 2011).

Seventh, the use of a life course perspective in research for political practice gives the opportunity to correct public policies when they are less and less in line with actual life course patterns in a given society. For example, the retirement of the baby boom generation is associated with a greater demand from older people for recreational, educational and cultural services than in the past.

Eighth, the observation of the life course of different cohorts allows us to change institutional and legal solutions in order to better adapt them to the new intergenerational relations. For example, the mass emigration of young people after Poland's accession to the European Union is causing a weakening of the care potential of families, which requires the development of services offered to the elderly by institutions.

Ninth, in the case of gerontological examinations, the joint work of a researcher and an elderly person on the production and evaluation of autobiographical material may play an important therapeutic and strengthening role. In gerontological psychology, attention is drawn to the important role of life recapitulation that should be done in old age.

As with any research perspective, the life course perspective is not free from limitations.

First of all, the study of changes that occur in a person's life or community over time requires long-term, repeated observation. Such research is costly, requires a great deal of organizational effort and a strong institutional base that guarantees the continuation of research in the long term. 
Second, due to the limited possibilities of using experimental schemes in research, most of the claims concerning cause-and-effect relationships between the various variables studied remain hypotheses, as they are difficult to verify or falsify empirically.

Third, the subject of research: social constructions of the life course - empirical processes that make up the actual course of people's lives - is very complicated and multidimensional. This means that researchers quite arbitrarily reduce the study subject to the selected careers (trajectories) and transition moments. As a result, our knowledge about the life course is fragmented and it concerns different stages of life in different ways.

Fourth, in the two conceptualizations discussed above, life course is subject to an accelerated process of change, which means that the diagnoses prepared with a lot of effort become outdated relatively quickly.

Fifth, in the case of older people (due to cognitive disorders), the possibility of conducting research referring to memories is limited, and the state of health makes it difficult to obtain consent from respondents for participation in the research conducted in the form of interviews or questionnaires.

\section{Key research schemes}

There are numerous classifications of research patterns in social sciences. These classifications are based on a variety of criteria. Due to the criterion of manipulation, the independent variable is distinguished between experimental (laboratory or natural) and non-experimental (in developmental psychology it is also referred to as naturalisticcorrelative) studies (Brzezińska, Appelt and Ziółkowska, 2015, p. 98). Due to a number of criteria considered together, quantitative and qualitative research is distinguished. Similarly, the division into the following types of research design is multi-criteria: experiment, case study, longitudinal design, cross-sectional design (de Vaus, 2007). Due to the role assigned to the passage of time in the study, cross-sectional studies (recording the values of variables and relationships between variables at one selected time) and dynamic studies (recording changes in time, serving to observe processes) are distinguished. The typologies of research in which a time variable is taken into account are numerous in the methodology of social sciences. In further deductions, I am going to use the typology used by Earl Babbie (2010, pp. 106-112), which distinguishes: crosssectional studies, ${ }^{6}$ longitudinal studies, approximating longitudinal studies. Since the ageing of individuals and the ageing of the population are processes that extend over time, have many determinants and take place at many levels, a special role in social gerontology is played by dynamic and near-dynamic research. These studies can use various strategies. $^{7}$ Within longitudinal studies, ${ }^{8}$ Babbie distinguishes: trend study, ${ }^{9}$ cohort study ${ }^{10}$ and panel study. ${ }^{11}$ Trend study (also called repeated cross-sectional studies) consists in carrying out, at certain intervals, several (a dozen or so) measurements of the researched phenomenon in the whole population (e.g., in the course of the national census) or in research samples from this population (e.g., samples of respondents drawn by public opinion polling centers). If it is a study on samples, they are drawn randomly or otherwise selected before each subsequent measurement (the survey wave). As a result of trend research, the direction of change can be determined using data from surveys, national censuses, official documents, etc. The cohorts study analyzes the changes over time in the selected categories of population. A cohort is a collection of people who have a connection to some important event, such as being born in the same 
year, getting married in the same period, retiring in the same year. In the scheme called cohort testing, a representative sample of the cohort is selected before each subsequent measurement. This study is a kind of accompanying cohort at different stages of its life and observing the changes taking place. The third type distinguished by Babbie is panel research, which consists in taking several measurements on the same research sample. Such a sample can be created according to different rules of selection. It may consist, for example, of persons belonging to one or more cohorts of interest to the researcher. In the basic version of the panel study, the sample selection is made only once - before the first survey is carried out - and in the subsequent measurements, the researcher returns to the same people. There are also varieties of panel tests in which the composition of the sample is subject to controlled changes (e.g., single panel design with replacement, rotating panel design; de Vaus, 2007, pp. 120-123). Panel research allows for the most insightful tracking of the directions of changes in the observed variables. Their weakness is the fact that in subsequent measurements - especially when they take place in several-year intervals - the number of dropouts decreases, because the respondents no longer want to participate in the survey, they leave, die. Moreover, multiple participation in research on the same subject may have an impact on the opinions and behaviors of research participants, thus influencing their responses to the research to some extent, and thus changing the results of the research.

Studies similar to this dynamic are those in which conclusions concerning changes occurring over time are drawn on the basis of one measurement (i.e., cross-sectional studies). They can be carried out using different strategies. In gerontological studies, the most frequently used are cross-sectional studies of different age groups (treated as representing different phases of the life cycle or different stages of life course) and retrospective studies (respondents are asked for information about their past and current situation; life story method is an example). The first of these strategies involves the risk of misinterpreting the differences between age groups resulting from the process of maturation/ageing of individuals. Retrospective research, in turn, is burdened with errors resulting from the unreliability of the memory of respondents, the desire to consciously falsify the past or to unconsciously modify memories (filtering memories through later experiences).

Research close to this dynamic - despite its numerous limitations - is often carried out because of its undoubted advantage; its short duration, lower costs, easier organization of research. Studies of this kind can provide very interesting hypotheses about the changes in the phenomena studied over time. However, more reliable knowledge of change is provided by dynamic research, in which, to a certain extent, researchers observe the evolution of change.

In the interpretation of the results of dynamic and near-dynamic studies, in which we search for the essence and regularity of changes associated with the ageing of people, we must be very careful. The observed changes in time, changes in life patterns or differences between age groups may have different causes, which researchers (e.g., de Vaus, 2007; Green, 2017) describe as: age effect, cohort (generation) effect, period effect. Determining which of these reasons is the most important is a difficult task. Its implementation makes it easier to combine different patterns of research in one research project and to cover different cohorts. For example, so-called sequential analysis combining longitudinal and cross-sectional studies (Brzezińska, 2000) is a research strategy that can capture the impact of cohort, age and period effects. 


\section{Conclusion}

The adoption of a life course perspective in gerontological research is essential for a better understanding of old age as a stage in human life and an accurate diagnosis of the situation of people belonging to the older generation at a given time. This research perspective also has great potential for the development of human ageing theory and theory to explain changes in an ageing society. It has numerous cognitive and practical qualities. At the same time, it brings serious methodological challenges related to the use of dynamic research schemes and the specificity of the elderly as respondents.

\section{Notes}

1 For the purposes of social policy science, these two perspectives were described by B. RyszKowalczyk (2003).

2 "A sociology of the life course focuses on patterns, trends and change through individuals' lives, and how historical, societal and political norm, situations and transformations impact on them" (Green, 2017, p. 26).

3 Life span psychology has been described as the study of individual development (ontogenesis) - a lifelong adaptive process of acquisition, maintenance, transformation and attrition in psychological structures and functions... Nature and nurture are combined but much attention is focused on individual differences relating to ability and personality. These are seen to have a biological basis and genetic foundation which cause age-related variations across the life span.

(Green, 2017, p. 27)

4 As some researchers demonstrate, social actors do not mechanically adapt to the limitations and opportunities offered by the social system and cultural heritage, but rather "negotiate the available life course models" (Lalive d'Épinay et al., 2005).

5 I assume, after Piotr Sztompka, that

culture is a network of meanings, produced by people, but for each of them separately external, inherited from generation to generation and historically changeable.... What distinguishes cultural meanings is their normative, obligatory character. Cultural meanings are values worthy of cultivating.

(Sztompka, 2019, p. 21)

6 "A study based on observations representing a single point in time" (Babbie, 2010, p. 106).

7 A wider presentation on the topic is made by, among others: Koseła and Sułek (1986), Brzezińska (2000), de Vaus (2007), Brzezińska, Appelt and Ziółkowska (2015).

8 It should be noted that the concept of longitudinal study (research, design) occurs in the scientific literature in two meanings: broad - "a study design involving the collection of data at different points in time" (Babbie, 2010, p. 107) and narrow - as research conducted for subsequent measurements on the same samples (e.g., Brzezińska, 2000; de Vaus, 2007; Frątczak, 2014).

9 "A type of longitudinal study in which a given characteristic of some population is monitored over time" (Babbie, 2010, p. 107).

10 "A study in which some specific subpopulation, or cohort, is studied over time, although data may be collected from different members in each set of observations" (Babbie, 2010, p. 108).

11 "A type of longitudinal study, in which data are collected from the same set of people (the sample or panel) at several points in time" (Babbie, 2010, p. 109).

\section{References}

Babbie, E. (2010). The practice of social research. 12th ed. Belmont, CA: Wadsworth, Cengage Learning.

Brzezińska, A. (2000). Społeczna psychologia rozwoju. Warszawa: Scholar. 
Brzezińska, A.I., Appelt, K. and Ziółkowska, B. (2015). Psychologia rozwoju człowieka. Sopot: Gdańskie Wydawnictwo Psychologiczne.

Côté, N. (2013). Pour une compréhension dynamique du rapport au travail: la valeur heuristique de la perspective des parcours de vie. Sociologie et societés, 45(1).

de Vaus, D.A. (2007). Research design in social research. London, Thousand Oaks, CA and New Delhi: SAGE Publications.

Dobrowolska, D. (1992). Przebieg życia - fazy - wydarzenia. Kultura i Społeczeństwo, XXXVI(2).

Frątczak, E. (2014). Analiza danych wzdłużnych: wybrane zagadnienia. In: E. Frątczak, A. Kamińska and J. Kordos (eds), Statystyka: zastosowania biznesowe i społeczne. Warszawa: Wydawnictwo Wyższej Szkoły Menedżerskiej im. Prof. Leszka J. Krzyżanowskiego.

Green, L. (2017). Understanding the life course: sociological and psychological perspectives. 2nd ed. Cambridge, UK: Polity Press.

Guillaume, J.-F. (2005). Introduction. In: J.-F. Guillaume, Ch. Lalive d'Epinay and L. Thomsin (eds), Parcours de vie: regards coisés sur la construction des biographies contemporaines. Liège: Les Editions de l'Université de Liège.

Hajduk, E. (2001). Kulturowe wyznaczniki biegu życia. Warszawa: Wydawnictwo Akademickie "Żak".

Koseła, K. and Sułek, A. (1986). Metody badania procesów społecznych. In: A. Sułek (ed.), Metody analizy socjologicznej, Wybór tekstów. Warszawa: Wydawnictwa Uniwersytetu Warszawskiego.

Lalive d'Einay, Ch., Cavalli, S. and Guilley, E. (2005). Parcours de vie et vieillesse. In: J.-F. Guillaume, Ch. Lalive d'Epinay and L. Thomsin (eds), Parcours de vie: regards coisés sur la construction des biographies contemporaines. Liège: Les Editions de l'Université de Liège.

Lalive d'Épinay, Ch., Bickel, J.-F., Spini, D. and Cavalli, S. (2005). Parcours de vie: émergence d'un paradigme interdisciplinaire. In: J.-F. Guillaume (ed.), Parcours de vie: regards coisés sur la construction des biographies contemporaines. Liège: Les Editions de 1'Université de Liège.

MacDaniel, S. and Bernard, P. (2011). Life course as a policy lens: challenges et opportunities. Canadian Public Policy/Analyse de Politiques, 37, Special Supplement on The Life Course as a Policy Lens. Available at: www.jstor.org/stable/pdf/24465932.pdf [Accessed 10 April 2019].

Roselli, N.D. (2015). Les âges de la vie, une répresentation sociale. International Psychology, Practice and Research, 6, 1-24.

Rysz-Kowalczyk, B. (1996). Pokolenie w fazie późnej dojrzałości: Deformacje cyklu życia $i$ zagrożenia społeczne we wspótczesnej Polsce. Warszawa: IPS UW.

Rysz-Kowalczyk, B. (2003). Czas życia człowieka: dwie perspektywy poznawcze. In: B. RyszKowalczyk and B. Szatur-Jaworska (eds), Wokót teorii polityki społecznej. Warszawa: IPS UW.

Szatur-Jaworska, B. (2000). Ubóstwo osób w wieku podeszłym: przyczynek empiryczny. Problemy Polityki Społecznej. Studia i Dyskusje, 2.

Szatur-Jaworska, B. (2014). Starość w polskiej rodzinie. In: P. Szukalski (ed.), Relacje międzypokoleniowe we wspótczesnych polskich rodzinach. Łódź: Wydawnictwo Uniwersytetu Łódzkiego.

Sztompka, P. (2019). O pojęciu kultury raz jeszcze. Studia Socjologiczne, 1(323). 